\title{
Initial performance of 'Gem' avocado trees in the Central-Western region of São Paulo State
}

\section{Desempenho inicial de abacateiros 'Gem' na Região Centro-Oeste do Estado de São Paulo}

\author{
Lígia Broglio Micheletti1*; Tatiana Cantuarias Avilés²; Edypol Guilherme Baptista; \\ Mariana Freire Alberti; Guilherme Nacata1; Bruna do Amaral Brogio1; \\ Simone Rodrigues da Silva ${ }^{5}$
}

\section{Highlights}

In a tropical wet-dry climate 'Gem' is harvested 3 to 7 months later than 'Hass'.

'Gem' upright growth habit makes it a suitable cultivar for high-density plantations.

'Gem' yields higher percentages of the most profitable size classes.

'Gem' is a new cultivar option and allows higher profit to the farmers.

\begin{abstract}
The introduction of new avocado cultivars into producing countries of the Southern Hemisphere may extend the offer period of fresh fruit for export. The 'Gem' ('3-29-5') avocado is known for extending the marketing period of 'Hass'-like avocados. This study aimed to evaluate the horticultural performance of 'Gem' avocado trees between the $4^{\text {th }}$ and $6^{\text {th }}$ years after planting (2016-2018), in a commercial orchard in the Central-Western region of the State of São Paulo, Brazil. 'Gem' avocado trees grafted onto seedling rootstocks were evaluated regarding tree size, shoot growth, flowering, and fruit yield, quality and maturation. In the evaluated biennium, the trees showed a strong upright growth habit and compact tree size. Flowering occurred mainly in indeterminate inflorescences. Fruit yield varied between 106.89 to $116.89 \mathrm{~kg} \mathrm{tree}^{-1}$, and $75-91 \%$ of the fruit classified within size counts 12 (306 to $365 \mathrm{~g} /$ fruit) to 18 (211 to $235 \mathrm{~g} /$ fruit), and reached physiological maturity in late June, but could be picked until October, i.e, four to eight months later than 'Hass'. 'Gem' is a new alternative for extending fruit offer of late-maturity avocado cultivars and allowing higher profit to the farmers.
\end{abstract}

Key words: Flowering. 'Hass'-like avocados. Persea americana Mill. Vegetative growth. Yield.

1 PhD Students of Postgraduate Program in Plant Production, Escola Superior de Agricultura "Luiz de Queiroz", Universidade de São Paulo, ESALQ/USP, Piracicaba, SP, Brazil. E-mail: ligiabmicheletti@gmail.com; guilherme. nacata@gmail.com; b.brogio@gmail.com

2 Crop Advisor and Researcher, Piracicaba, SP, Brazil. E-mail: tatiana.cantuarias@gmail.com

${ }^{3}$ PhD Student, Centro de Energia Nuclear na Agricultura, Universidade de São Paulo, CENA/USP, Piracicaba, SP, Brazil. E-mail: edypol_0@hotmail.com

${ }^{4}$ MSc, ESALQ/USP, Piracicaba, SP, Brazil. E-mail: mariana.falberti@gmail.com

Profa $^{a}$, PhD, ESALQ/USP, Piracicaba, SP, Brazil. E-mail: srsilva@usp.br

* Author for correspondence

Received: Mar. 03, 2021 - Approved: Apr. 05, 2021 


\section{Resumo}

A introdução de novas cultivares de abacate em países produtores do Hemisfério Sul pode estender o período de oferta do fruto fresco para exportação. O abacate 'Gem' ('3-29-5') é conhecido por estender o período de comercialização de abacates do tipo 'Hass'. Este estudo teve como objetivo avaliar o desempenho horticultural de abacateiros 'Gem' entre o $4^{\circ}$ e $6^{\circ}$ anos após o plantio (2016-2018) em pomar comercial na região Centro-Oeste do Estado de São Paulo, Brasil. Os abacateiros 'Gem' enxertados em porta-enxertos obtidos de sementes foram avaliados em relação ao tamanho da árvore, crescimento do broto, florescimento e produção, qualidade e maturação de frutos. No biênio avaliado, as árvores apresentaram forte hábito de crescimento ereto e tamanho compacto. O florescimento ocorreu principalmente com inflorescências indeterminadas. A produção variou entre 106,89 a 116,89 kg/planta e 75-91\% dos frutos classificados nas categorias de calibre 12 (306 a 365 g/fruto) a 18 (211 a 235 g/fruto), e atingiram a maturidade fisiológica no final de junho, podendo ser colhido até outubro, ou seja, quatro a oito meses depois de 'Hass'. 'Gem' é uma nova alternativa para estender a oferta de cultivares de abacate de maturação tardia e permitir maior lucro aos agricultores.

Palavras-chave: Florescimento. abacates tipo 'Hass'. Persea americana Mill. Crescimento vegetativo. Produção.

\section{Introduction}

Fresh avocado (Persea americana Mill.) world market moved around 4.6 billion dollars in 2016, with a $46 \%$ growth related to 2006 (Food and Agriculture Organization [FAO], 2020), represented mostly by the 'Hass' cultivar, given its good acceptance by consumers worldwide (Crane et al., 2015).

Brazil is the sixth world avocado producer, with 235.788 tons harvested in 2018 over 14.331 hectares, mainly distributed in the Southeast, Northeast and South regions (FAO, 2020), and based on local selections of tropical cultivars to supply the domestic market (Salata \& Sampaio, 2008), which are unknown in the export markets where 'Hass' is the leading commercial standard (Fischer, Tozze, Arruda, \& Massola, 2011).

The consumption of 'Hass' avocados by Brazilians is still low, given its large differences with the tropical cultivars traditionally consumed in the country, in terms of its smaller fruit size, rough appearance and purple coloration of ripe fruit peel and high oil content in the pulp (Fischer et al., 2011; Crane et al., 2015; Duarte, Chaves, Borges, \& Mendonça, 2016). For these reasons, the Brazilian production of 'Hass' avocado serves mainly the foreign market (Salata \& Sampaio, 2008).

'Hass' avocados production in several countries with highly diverse edaphoclimatic conditions for its cultivation enables the offer of fresh fruit in the international market throughout the whole year. In 2017, the main producers in the Southern Hemisphere were responsible for supplying $24 \%$ of the demand of the consumers in the Northern Hemisphere in off-season periods (FAO, 2020).

Inthis context, new'Hass'-likeavocados which have been selected and released in other countries offer economic advantages regarding yield precocity, productivity, lower 
tendency to alternate bearing, good fruit size and postharvest quality (Van-Rooyen, 2011).

The 'Gem' or '3-29-5' 'cultivar was developed by the avocado breeding program of the University of California at Riverside, USA, and originated from an open-pollinated seedling of 'Gwen' avocado ('Thille' $\times$ 'Hass'). It was patented and commercially released in 2003 (Arpaia \& Menge, 2004), with exclusive license given to the South African company Westfalia Technological Services to develop and market 'Gem' internationally outside the USA.

In field trials carried out in South Africa and the USA, the 'Gem' avocado was promising, mainly because of its latematuration and high fruit quality, which allow extending the marketing period of 'Hass'-like fruit (Van-Rooyen, 2011; Crane et al., 2015).

Therefore, the aim of this research was to characterize fruit ripening, vegetative growth, flowering and production of 'Gem' avocado trees under the prevailing edaphoclimatic conditions of the CentralWestern region of the State of São Paulo, Brazil.

\section{Materials and Methods}

The study was conducted between 2016 and 2018 in an experimental plot of 'Gem' avocado trees (Persea americana Mill.) planted in a commercial orchard in Arealva, in the Central-Western region of the State of São Paulo, Brazil (22¹0'23" S, 49¹'44" W and $580 \mathrm{~m}$ altitude). The local climate is Aw, according to Köppen-Geiger's classification, i.e., tropical wet climate with dry winter (Centro de Pesquisas Meteorológicas e Climáticas Aplicadas a Agricultura [CEPAGRI], 2016).
During the experimental period, meteorological data were recorded by an automated weather station located in Bauru, at 27-km distance from the experimental site (Table 1) (Instituto Nacional de Meteorologia [INMET], 2018).

The experimental plot was planted in the March 2012, in a spacing of $8 \times 4 \mathrm{~m}$ (312 trees ha-1), with 'Gem' trees grafted onto seedling rootstocks of unknown origin. Each tree was irrigated by one micro sprinkler with volume of $20 \mathrm{~L} /$ hour per plant. All trees received grower standard cultural traits recommended for avocado trees (Whiley, Wolstenholme, \& Faber, 2013).

Between 2016 and 2018 (year 4 to 6 after planting), nine 'Gem' trees of the same age were evaluated regarding tree size, vegetative growth, flowering, fruit yield, size, shape and pulp dry matter content over the ripening period. As in other studies, the reduced number of trees in the experimental plot is due to the processes for obtaining plants with exclusive license, which requires the importing of plant material (Dixon, Cotterell, Hofstee, \& Elmsly, 2008).

In years 2016 and 2017, pulp dry matter percentage (DM) was determined after a methodology adapted from Aldana, Longas and Lozano (2010), by weight difference determination on $30 \mathrm{~g}$ pooled pulp samples dried in a microwave oven until constant weight, as follows: $(\mathrm{DM}(\%)=($ dry weight/fresh weight) $\times 100$ ) .

Canopy volume (V) was calculated from individual measurements of tree height $(\mathrm{H})$, down-row canopy width (Dw) and acrossrow canopy width (Aw) collected immediately after harvest, by using the formula: $V\left(\mathrm{~m}^{3}\right)=$ $4 / 3 \cdot \pi \cdot H \cdot(D w+A w / 2)^{2}$ (Mickelbart, Bender, Witney, Adams, \& Arpaia, 2007). 
Table 1

Mean monthly values of total rainfall (R), minimum (Tmin), maximum (Tmax) and mean (Tmed) air temperature, and relative air humidity (RH) between April 2016 and June 2018. Bauru meteorological station, SP, Brazil

\begin{tabular}{|c|c|c|c|c|c|c|c|c|c|}
\hline & 04/2016 & 05/2016 & 06/2016 & 07/2016 & $08 / 2016$ & $09 / 2016$ & 10/2016 & 11/2016 & 12/2016 \\
\hline $\mathrm{R}(\mathrm{mm})$ & 33.4 & 96.6 & 82.2 & 7.2 & 54.2 & 21.6 & 91.4 & 78.0 & 126.4 \\
\hline $\operatorname{Tm} i n\left({ }^{\circ} \mathrm{C}\right)$ & 12.6 & 12.9 & 9.3 & 11.0 & 12.0 & 14.2 & 17.0 & 17.3 & 20.2 \\
\hline $\operatorname{Tmax}\left({ }^{\circ} \mathrm{C}\right)$ & 27.3 & 22.7 & 21.7 & 24.1 & 25.4 & 26.8 & 29.6 & 27.6 & 28.2 \\
\hline Tmed $\left({ }^{\circ} \mathrm{C}\right)$ & 23.9 & 18.5 & 16.7 & 18.5 & 19.7 & 20.2 & 22.3 & 22.9 & 24.0 \\
\hline \multirow[t]{2}{*}{ RH (\%) } & 67.2 & 79.4 & 77.6 & 63.7 & 63.9 & 63.8 & 69.2 & 71.9 & 74.2 \\
\hline & $01 / 2017$ & $02 / 2017$ & 03/2017 & $04 / 2017$ & 05/2017 & $06 / 2017$ & 07/2017 & 08/2017 & 09/2017 \\
\hline $\mathrm{R}(\mathrm{mm})$ & 393.4 & 114.8 & 102.0 & 100.0 & 168.0 & 20.0 & 0.2 & 60.6 & 13.0 \\
\hline $\operatorname{Tmin}\left({ }^{\circ} \mathrm{C}\right)$ & 20.5 & 21.3 & 20.4 & 17.1 & 17.0 & 11.1 & 11.0 & 14.8 & 18.0 \\
\hline $\operatorname{Tmax}\left({ }^{\circ} \mathrm{C}\right)$ & 27.2 & 28.0 & 27.4 & 25.6 & 23.4 & 23.2 & 24.1 & 24.7 & 26.8 \\
\hline Tmed $\left({ }^{\circ} \mathrm{C}\right)$ & 23.5 & 24.9 & 23.5 & 21.6 & 20 & 18 & 17.5 & 19.3 & 23.4 \\
\hline \multirow[t]{2}{*}{ RH (\%) } & 81.9 & 73.6 & 75.4 & 77.0 & 80.6 & 75.5 & 65.0 & 66.5 & 50.3 \\
\hline & $10 / 2017$ & $11 / 2017$ & $12 / 2017$ & $01 / 2018$ & $02 / 2018$ & 03/2018 & $04 / 2018$ & $05 / 2018$ & $06 / 2018$ \\
\hline $\mathrm{R}(\mathrm{mm})$ & 104.8 & 221.4 & 96.8 & 219.0 & 79.8 & 204.8 & 13.2 & 9.2 & 12.4 \\
\hline $\operatorname{Tmin}\left({ }^{\circ} \mathrm{C}\right)$ & 17.6 & 19.5 & 20.4 & 20.0 & 19.9 & 21.3 & 19.7 & 11.9 & 15.9 \\
\hline $\operatorname{Tmax}\left({ }^{\circ} \mathrm{C}\right)$ & 28.9 & 27.9 & 27.3 & 27.7 & 26.8 & 28.2 & 24.8 & 24.6 & 24.3 \\
\hline Tmed $\left({ }^{\circ} \mathrm{C}\right)$ & 22.9 & 22.5 & 24.2 & 23.5 & 23.2 & 24.5 & 22.2 & 20.1 & 19.8 \\
\hline RH (\%) & 69.2 & 72.6 & 73.6 & 79.9 & 75.2 & 78.8 & 72.4 & 68.4 & 69.0 \\
\hline
\end{tabular}

Source: INMET (2018).

Vegetative growth was estimated from monthly shoot length measurements on five shoots on each tree, tagged in the mid-portion of the canopy. Shoot extension was measured from a marked reference at the basal bud ring to the base of the terminal bud, by using a cloth measuring tape. Average shoot growth rate was then calculated from the variation among consecutive measurements at four different periods, and it was assessed separately on shoots of the summer vegetative growth from April to August 2016, and on shoots of the late-winter/spring flushing, measured from August to December 2017.
In August 2016 and 2017, at full bloom, the mean number of panicles and the percentage of determinate and indeterminate inflorescences were evaluated (Alcaraz, Thorp, \& Hormaza, 2013) on five tagged shoots per tree, evenly distributed around the mid-portion of the canopy. Additionally, the intensity of flowering was visually assessed on each tree by using a five-score rating scale (scores 0 to 5 , where 0 accounts for a flowerless canopy; scores 1, 2, 3 and 4 represent trees with up to $20 \%, 40 \%$ and $60 \%$ of the canopy with panicles, respectively; and score 5 runs for trees with more than $80 \%$ of the canopy area with panicles) (Cristoffanini, 1996). 
Fruit yield per tree was annually computed at harvest (June 2017 and July 2018), by counting and weighing all the fruits picked from each measured tree. Yield efficiency (YE) was calculated by using the expression: YE $\left(\mathrm{kg} \mathrm{m}^{-3}\right)=$ Yield ( $\mathrm{kg} /$ tree)/Canopy volume $\left(\mathrm{m}^{3}\right)$. Productivity $\left(\mathrm{t} \mathrm{ha}^{-1}\right)$ was calculated by multiplying the average fruit yield per tree by the planting density.

Annually at harvest, a sample of 100 fruits was randomly collected from all the trees for individual measurements of fruit weight, length (L), diameter (D) and the L:D ratio that characterizes fruit shape. Individual fruit weight was utilized to estimate fruit size distribution using the count size classes valid for 'Hass' avocados sold in the European market, as follows: class 10 (>365 g), class 12 (306 to 365 g), class 14 (266 to 305 g), class 16 (236 to $265 \mathrm{~g}$ ), class 18 ( 211 to $235 \mathrm{~g}$ ), class 20 (191 to $210 \mathrm{~g}$ ), class 22 (171 to $190 \mathrm{~g}$ ), class 24 (156 to $170 \mathrm{~g})$, class 26 (146 to $155 \mathrm{~g})$, class
28 (136 to $145 \mathrm{~g}$ ), class 30 (125 to $135 \mathrm{~g}$ ) and small-sized fruit (<125 g) (Hofman, Fuchs, \& Milne, 2002; Organisation for Economic Cooperation and Development [OECD], 2004).

\section{Results and Discussion}

In 2017, 'Gem' fruit was harvested in June 23, four months later than 'Hass' fruit picked on February 22 in the same orchard. In June, 'Gem' was harvested with $27.9 \%$ mean pulp dry matter content, slightly above the minimum recommended content of $27 \%$ for harvesting other late-maturing avocado cultivars, such as 'Lamb Hass', that guarantees a good palatability and no fruit shrinkage after harvest (Dixon et al., 2008). On that year, it was decided to store a portion of the fruit on the trees until mid-spring (October), when pulp dry matter content was close to $35 \%$ (Figure 1), i.e., eight months later than 'Hass'.

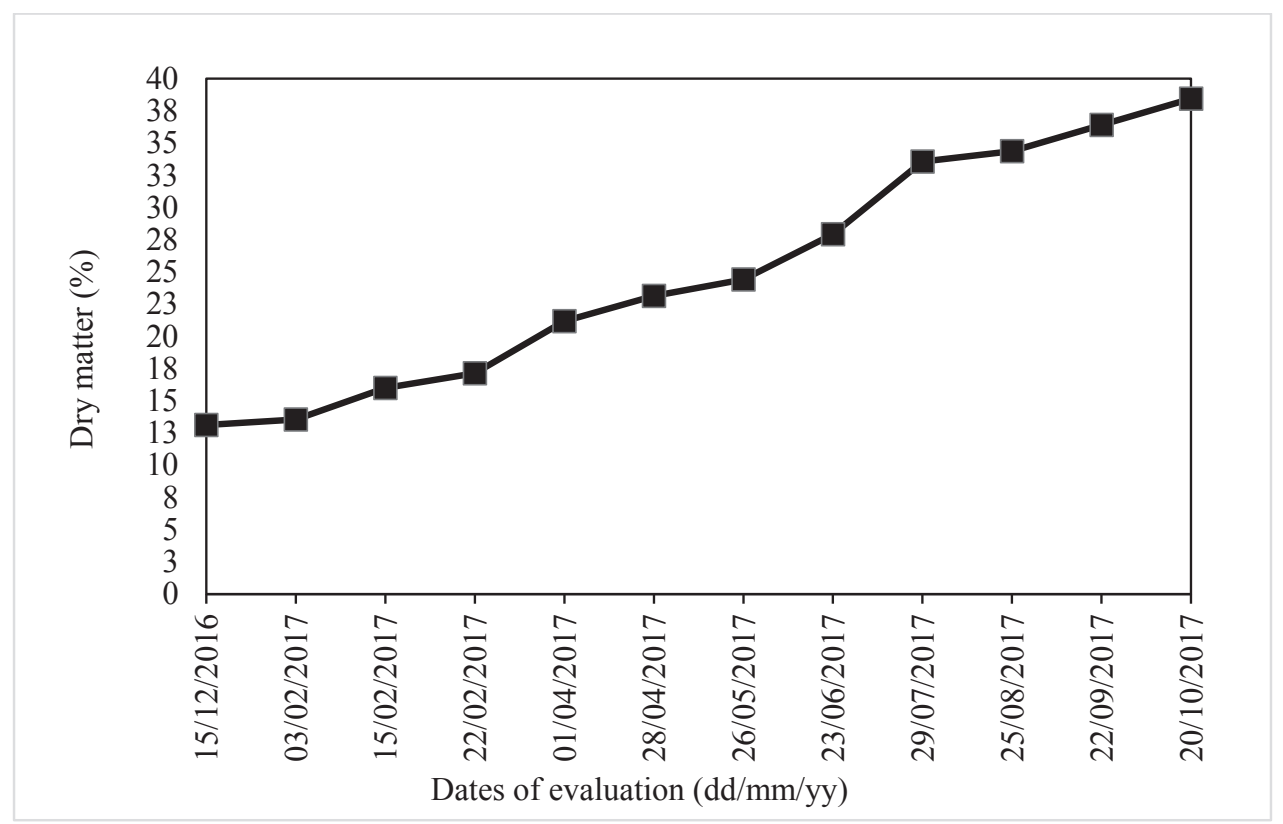

Figure 1. Evolution of the mean pulp dry matter percentage (\%) of 'Gem' avocados in the 20162017 season. Arealva, SP, Brazil. 
The 'Gem' avocado cultivar is known for its later maturation compared with 'Hass' (Crane et al., 2015). Minimum pulp dry matter content for harvesting this cultivar corresponds to $27 \%$, when fruit presents good palatability and firmness (Blakey et al., 2015). According to Blakey et al. (2015), because of its late maturation, the minimum dry matter content does not become so decisive to define the beginning of the harvest, which can occur with up to $38 \%$ pulp dry matter. In New Zealand, Dixon et al. (2008) harvested this cultivar with 31.9 to $37.7 \%$ of dry matter, between November and January. Skin color of late-harvested fruit turned darker and purplish, which is characteristic of ripe fruit of the 'Gem' cultivar (Arpaia et al., 2013).

In South Africa, 'Gem's late maturation allows to delays fruit harvest by 4 weeks after the end of the 'Hass' harvesting season (Bekker, 2012), and it can be extended for up to 2 months, depending on the region of cultivation (Van-Rooyen, 2011). Under the prevailing edaphoclimatic conditions in the present study, 'Gem' fruit reached the minimum maturity index of $27 \%$ pulp dry matter at the end of June, four months after the beginning of the 'Hass' harvesting period in the same location, which occurred between the end of February until the end of April. When hung on the tree, 'Gem' fruit could be harvested until October, thus extending the supply period of 'Hass'-like fruit by around 8 months in regions with tropical climate with wet summer and dry winter conditions, such as those prevailing in this study (Table 1). Extended fruit supply could also be possible by growing the 'Gem' avocado in other regions of the São Paulo and Minas Gerais states, at higher altitude and under a milder climate favorable for later fruit maturation (Sentelhas, Piza, Alfonsi, Kavati, \& Soares, 1995).

In the 2017-2018 biennium $\left(5^{\text {th }}\right.$ to $6^{\text {th }}$ year after planting), 'Gem' trees showed a strong upright growth habit, with mean variation of tree height and across-row width of $5.70 \%$ and $2.06 \%$, respectively (Table 2), thus confirming the slow initial growth and low vigour described for this cultivar by Bruwer and Mokgalabone (2005) and Bruwer (2007).

\section{Table 2}

Mean and standard error of the mean values for tree height $(\mathrm{H})$, down-row width (Dw), across-row width (Aw) and canopy volume (V) of 5- and 6-year- old 'Gem' avocado trees. Arealva, SP, Brazil, 2017-2018

\begin{tabular}{cccccc} 
& & Dw & Aw & V \\
\cline { 2 - 5 } Year & & $(\mathrm{m})$ & & \\
2017 & $4.03 \pm 0.09$ & $2.99 \pm 0.12$ & $2.91 \pm 0.15$ & $18.72 \pm 1.80$ \\
2018 & $4.26 \pm 0.11$ & $3.06 \pm 0.16$ & $2.97 \pm 0.11$ & $20.52 \pm 1.94$ \\
Variation in the period (\%) & 5.70 & 2.34 & 2.06 & 9.62
\end{tabular}


The upright habit and slow initial growth of 'Gem' avocado trees make this cultivar very suitable for the establishment of dense plantations (Crane et al., 2015), which allows to delay tree pruning for a later stage, thus allowing an anticipated recovery of the initial orchard establishment and management costs. Another feature referred to this cultivar and observed in this study, consists in its bearing habit in the inside of the canopy, protecting fruit against wind and sun injures (Blakey et al., 2015).

In this study, 4-year-old 'Gem' avocado trees had higher shoot growth rates during the winter/spring vegetative growth, than in the summer growth (Table 3). Mean shoot growth rates varied between 0.03 and $0.15 \mathrm{~mm}^{\text {day }}{ }^{-1}$ for the summer flush shoots, and between 0.13 to $1.67 \mathrm{~mm} \mathrm{day}^{-1}$ for the winter/spring flush. In the KwaZulu-Natal province, in South Africa, Mazhawu (2016) recorded summer shoot growth rates between 0.025 and 0.3 $\mathrm{mm}$ day $^{-1}$ on 4-to 5-year old 'Gem' avocado trees. Regardless of the flush type, higher shoot growth rates were initially recorded in the first three months of evaluation, while minimum growth occurred towards the end of the evaluation period (Table 3). In the 20162017 biennium, 'Gem' avocado trees flowered profusely, with more than one inflorescence per shoot, predominantly of the indeterminate type (Table 4), which ends in a vegetative bud (Alcaraz et al., 2013).

\section{Table 3}

Mean monthly shoot growth rate $(\mathrm{mm}$ day-1) at four periods during the summer and winter/spring vegetative flushes on 4-year-old 'Gem' avocado trees. Arealva, SP, Brazil, 2016

\begin{tabular}{|c|c|c|c|}
\hline \multicolumn{4}{|c|}{ Average summer shoot growth rate \pm standard error of the mean $\left(\mathrm{mm} \mathrm{day}^{-1}\right)$} \\
\hline 22 Apr-27 May & 27 May-8 Jul & $8 \mathrm{Jul}-27 \mathrm{Jul}$ & 27 Jul-26 Aug \\
\hline $0.15 \pm 0.02$ & $0.13 \pm 0.02$ & $0.17 \pm 0.04$ & $0.03 \pm 0.01$ \\
\hline \multicolumn{4}{|c|}{ Average winter/spring shoot growth rate \pm standard error of the mean $\left(\mathrm{mm}\right.$ day $\left.^{-1}\right)$} \\
\hline 26 Aug-30 Sep & 30 Sep-4 Nov & 4 Nov-25 Nov & 25 Nov-15 Dec \\
\hline $1.67 \pm 0.17$ & $0.37 \pm 0.07$ & $1.20 \pm 0.23$ & $0.13 \pm 0.04$ \\
\hline
\end{tabular}

\section{Table 4}

Average and standard error of the mean values for flowering intensity, number of panicles per shoot and percentage of determinate and indeterminate inflorescences in 4- and 5-year-old 'Gem' avocado trees. Arealva, SP, Brazil, 2016-2017

\begin{tabular}{ccccc} 
Year & $\begin{array}{c}\text { Flowering intensity } \\
\text { score* }^{*}\end{array}$ & Panicles per shoot & \multicolumn{2}{c}{ Type of inflorescence (\%) } \\
\cline { 4 - 5 } 2016 & $3.67 \pm 0.33$ & $2.13 \pm 0.27$ & $77.78 \pm 10.77$ & $22.22 \pm 10.77$ \\
2017 & $4.00 \pm 0.29$ & $1.56 \pm 0.12$ & $96.14 \pm 2.68$ & $3.86 \pm 2.68$
\end{tabular}

*Visually evaluated with a five-score rating scale, with $0=$ flowerless canopy and $5=$ over $80 \%$ of the canopy area with panicles (Cristoffanini, 1996). 
In the 2017-2018 period (years 5- 6 after planting), there was an increase in all yield variables. Mean productivity increased from 8.29 to $9.51 \mathrm{t} \mathrm{ha}^{-1}$, which is equivalent to a $14.72 \%$ increase in the period (Table 5). In Danroc, in the Mpumalanga province in South Africa, two-year-old 'Gem' avocado tress yielded $7 \mathrm{t} \mathrm{ha}^{-1}$ in their first harvest, whereas 'Hass' trees produced $6 \mathrm{t} \mathrm{ha}^{-1}$ (Bruwer, 2007). In Limpopo, also in South Africa, 'Gem' showed consistent yields over a period of six years, with a mean annual productivity of $23 \mathrm{t} \mathrm{ha}^{-1}$ (Bruwer \& Mokgalabone, 2005). Similarly, under the subtropical conditions of Karkloof, South Africa, four-year-old 'Gem' avocado trees grafted on the Dusa ${ }^{\circledR}$ clonal rootstock yielded 16 t ha-1 $^{-1}$ (Blakey et al., 2015). In Howick, KwaZulu-Natal, South Africa, Stones, Van Rooyen and Köhne (2017) reported a mean productivity of $18.13 \mathrm{t} \mathrm{ha}^{-1}$ in 'Gem' avocado trees grafted on 'Dusa' clonal rootstock between year 4 to 6 after planting. Under the conditions of this study, 'Gem' avocado cultivar showed lower productivity than that reported in South Africa, likely because of the more stressful local climatic conditions (Table 1) and the use of seedling rootstocks that induce lower productivity to the scion compared with the 'Dusa' clonal rootstock (Salata \& Sampaio, 2008).

\section{Table 5}

Mean and standard error of the mean values for fruit yield, productivity and yield efficiency of 5- to 6-year-old 'Gem' avocado trees in the 2017-2018 period. Arealva, SP, Brazil

\begin{tabular}{|ccccc|}
\multirow{2}{*}{ Year } & Fruits per tree & Fruit yield & Productivity & Yield efficiency \\
\cline { 3 - 5 } & & $\mathrm{kg} /$ tree & $\mathrm{t} \mathrm{ha}^{-1}$ & $\mathrm{~kg} \mathrm{~m}^{-3}$ \\
\hline 2017 & $106.89 \pm 29.87$ & $26.53 \pm 7.03$ & $8.29 \pm 2.20$ & $1.71 \pm 0.52$ \\
2018 & $116.89 \pm 32.24$ & $30.43 \pm 7.20$ & $9.51 \pm 2.25$ & $1.79 \pm 0.51$ \\
Variation in the period (\%) & 9.36 & 14.70 & 14.72 & 4.68 \\
\hline
\end{tabular}

In the 2018 harvest, larger fruit weight, length and diameter were recorded, despite of no variation observed on the L:D ratio, compared to the previous harvest (Table 6), indicating a proportional increment in both fruit length and diameter, that did not modify fruit shape. In the evaluated biennium, fruit weight was larger than $235 \mathrm{~g}$ reported by Crane et al. (2015) for the 'Gem' cultivar in California, under a Mediterranean climate. In Levubu, in the province of Limpopo in South Africa, under a subtropical mountain climate, larger average 'Gem' fruit weight was reported in the first harvest evaluated after pruning for canopy reduction (Bruwer \& Mokgalabone, 2005). On the other hand, mean fruit length (96 to $99 \mathrm{~mm}$ ) and diameter (74 to $76 \mathrm{~mm}$ ) observed in this study (Table 6) are similar to those reported by Dixon et al. (2008) for the 'Gem' avocado in the temperate climate of New Zealand (fruit length between 89.3 to $100.2 \mathrm{~mm}$ and diameter between 70.7 to 80.4 $\mathrm{mm})$. 
Table 6

Mean and standard error of the mean values for fruit weight, length (L), diameter (D) and L:D ratio of 'Gem' avocados in the 2017-2018 period. Arealva, SP, Brazil

\begin{tabular}{|ccccc}
\hline & Weight & Length $(\mathrm{L})$ & Diameter $(\mathrm{D})$ & L:D ratio \\
\cline { 2 - 4 } & $(\mathrm{g})$ & \multicolumn{2}{c}{$(\mathrm{mm})$} & \\
\hline 2017 & $270.70 \pm 21.59$ & $96.00 \pm 3.30$ & $74.00 \pm 1.90$ & $1.30 \pm 0.02$ \\
2018 & $297.40 \pm 16.12$ & $99.00 \pm 2.20$ & $76.00 \pm 1.40$ & $1.30 \pm 0.02$ \\
Variation in the period (\%) & 9.86 & 3.13 & 2.70 & 0.00 \\
\hline
\end{tabular}

In 2017 and 2018, 75\% and 91\% of the harvested fruit were distributed into size classes interval from 12 (306 to $365 \mathrm{~g}$ ) to 18 (211 to $235 \mathrm{~g}$ ), with higher commercial value (Hofman et al., 2002) (Figure 2). Regarding fruit size distribution, Bruwer and Mokgalabone (2005) reported that the 'Gem' avocado produced most of the fruit within $14(20 \%)$, $16(28 \%)$ and $18(12 \%)$ size classes. Stones et al. (2017) reported higher percentages of 'Gem' fruit classified within 12 (27.3\%) and 14 (19.0\%) size classes. In the 2017-2018 period evaluated in this study, the 'Gem' avocado yielded higher percentages of large fruit size classes, with 20 to $40 \%$ of the fruit classified in the 12-count class; 25 to $30 \%$ in the 14 -class, and between 10 to $14 \%$ in the 16-count class (Figure 2). According to Bruwer and Mokgalabone (2005), 'Gem' avocados weighing between 250 and $350 \mathrm{~g} \mathrm{(12} \mathrm{to}$ 16 -count classes) are preferred in most of the markets, although excessively big fruit are no longer preferred by the consumers and had lower commercial value (Blakey et al., 2015).

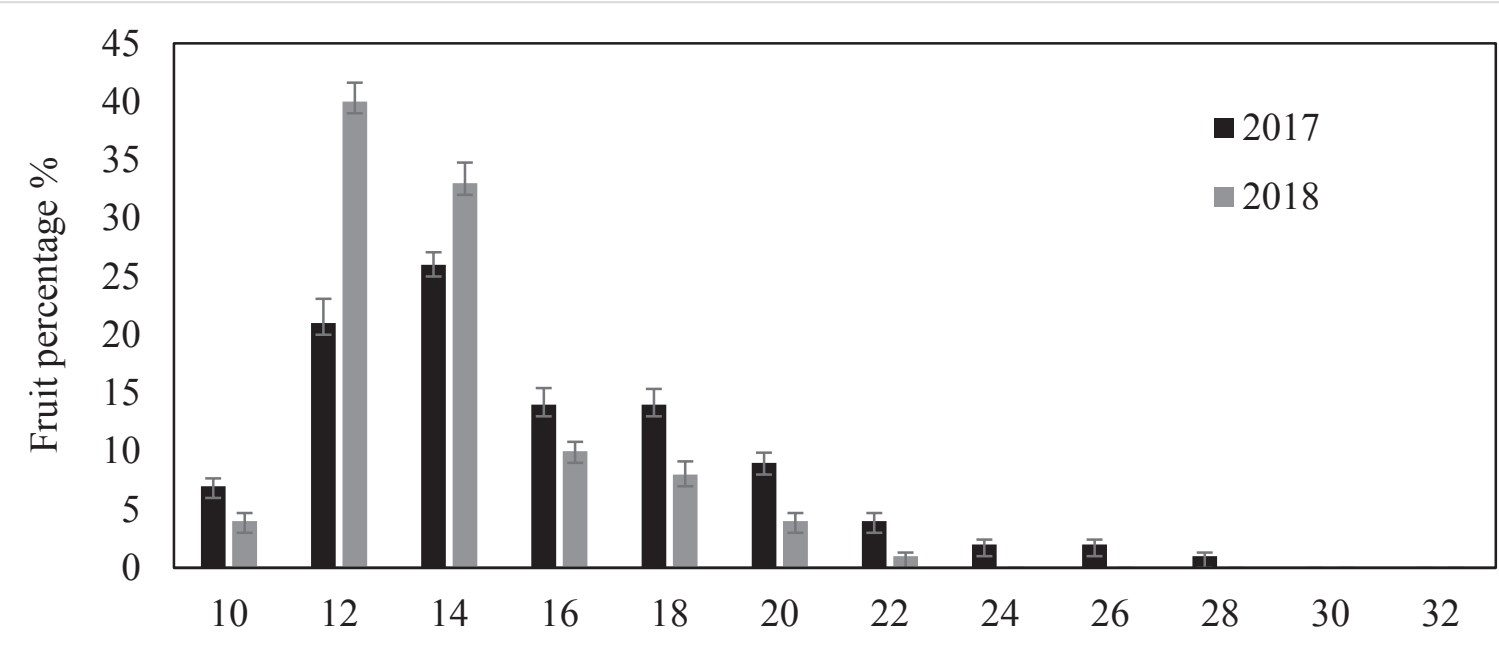

Count size class

Figure 2. Percentage of 'Gem' avocado fruit classified into different count size classes in 2017 and 2018. Arealva, SP, Brazil. 


\section{Conclusions}

In the Center-Western region of the State of São Paulo in Brazil, under tropical wetdry climatic conditions, the 'Gem' avocado yields highly-valued large sized fruit which can be lately harvested, thus extending the marketing period of 'Hass'-type avocados by 4 to 8 months.

'Gem' avocado trees have a strong upright growth, which suggests better suitability of this cultivar for high-density plantings.

The 'Gem' cultivar emerges as a new option for late production of high-quality avocados.

\section{Acknowledgements}

The first author acknowledges CAPES for the Master's degree student fellowship, and the last author acknowledges Conselho Nacional de Desenvolvimento Científico e Tecnológico (CNPq) for the research fellowships Special thanks are given to Westfalia Tecnological Services for authorizing and financing this research, and to Jaguacy Brazil for providing their fields for this study.

\section{References}

Alcaraz, M. L., Thorp, T. G., \& Hormaza, J. I. (2013). Phenological growth stages of avocado (Persea americana) according to the $\mathrm{BBCH}$ scale. Scientia Horticulture, 164(2013), 434-439. doi: 10.1016/j.scienta. 2013.09.051

Aldana, A. S., Longas, F. F., \& Lozano, J. G. (2010). Postcosecha y transformación del aguacate. Colômbia: Corpoica.
Arpaia, M. L., \& Menge, J. A. (2004). Enhancement of avocado productivity. Plant improvement - selection and evaluation of improved varieties and rootstocks. Anais do Seminario Internacional de Paltos, Quillota, Chile, 2.

Arpaia, M. L., Bender, G. S., Francis, L., Menge, J. A., Shepherd, J. S., \& Smothers, V. W. (2013). Avocado production in California: a cultural handbook for growers. San Diego: University of California Cooperative Extension San Diego County and California Avocado Society.

Bekker, T. F. (2012). The effect of avocado consumer preferences and behaviour on the global commercialization of new avocado horticultural intellectual property. Gauteng: Research Report, University of South Africa. Recovered from https://pdfs.semanticscholar.org/1d 60/d0d82d58ef73eb0e06115ad65e337 3dfd795.pdf

Blakey, R. J., Van-Rooyen, Z., Köhne, J. S., Malapana, K. C., Mazhawu, E., Tesfay, S. Z., \& Savage, M. J. (2015). Growing avocados under shade netting in South Africa. Proceedings of Congreso Mundial de la Palta, Lima, Peru, 8.

Bruwer, A. T. (2007). Evaluation of the Hasslike avocado cultivars Harvest, Gem and Grace. South African Avocado Growers' Association Yearbook, 30, 32-33. Recovered from http://www. avocadosource.com/Journals/SAAGA/ SAAGA_2007/SAAGA_2007_V30_PGS_ 32-33_Bruwer.pdf

Bruwer, A. T., \& Mokgalabone, M. L. (2005). Evaluation of the hass-like avocado cultivars harvest, gem and grace at westfalia technological services. South 
African Avocado Growers' Association Yearbook, 28, 50-51. Recovered from http://www.avocadosource.com/Jour nals/SAAGA/SAAGA_2005/SAAGA_200 5_V28_PGS_50-51_Bruwer.pdf

Centro de Pesquisas Meteorológicas e Climáticas Aplicadas a Agricultura (2016). Clima dos municípios paulistas: Arealva. Recuperado de http://www.cpa.unicamp. br/outras-informacoes/clima_muni_040. html

Crane, J. H., Douhan, G., Faber, B. A., Arpaia, M. L., Bender, G. S., Balerdi, C. F., \& Barrientos-Priego, A. F. (2015). Cultivares y portainjertos. In B. Schaffer, B. N. Wolstenholme, \& A. W. Whiley (Eds.), El Aguacate: botânica, producción y usos (pp. 243-282). Valparaíso: Ediciones Universitarias de Valparaíso.

Cristoffanini, L. P. (1996). Caracterización de la floración en paltos (Persea americana Mill) cvs. Fuerte, Gwen, Whitsell y Esther. Quillota, Chile: Taller de Licenciatura, Universidad Católica de Valparaíso.

Dixon, J., Cotterell, C., Hofstee, B., \& Elmsly, T. A. (2008). University of California avocado cultivars 'Lamb Hass' and 'Gem' maturity and fruit quality results from New Zealand's evaluation trials. New Zealand Avocado Growers Association Annual Research Report, 8, 15-26. Recovered from http:// www.avocadosource.com/journals/nza ga/nzaga_2008/NZAGA_2008_02.pdf

Duarte, P. F., Chaves, M. A., Borges, C. D., \& Mendonça, C. R. B. (2016). Avocado: characteristics, health benefits and uses. Ciência Rural, 46(1), 747-754. doi: 10.1590/0103-8478cr20141516
Fischer, I. H., Tozze, H. J., Jr., Arruda, M. C., \& Massola, N. S., Jr. (2011). Póscolheita de abacates 'Fuerte' e 'Hass': características físicas químicas, danos e controle de doenças. Semina: Ciências Agrárias, 32(1), 209-220. doi: 10.5433/1679-0359.2011v32n1p209

Food and Agriculture Organization (2020). Food and agricultural commodities production. Retrieved from http://www. fao.org/faostat/en/\#home

Hofman, P. J., Fuchs, Y., \& Milne, D. L. (2002). Harvesting, packing, postharvest technology, transport and processing. In A. W. Whiley, B. Schaffer, \& B. N. Wolstenholme (Eds.), The avocado: botany, production and uses (pp. 363402). Wallingford: CAB International Press.

Instituto Nacional de Meteorologia (2018). Dados históricos anuais. Recuperado de https://bdmep inmet. gov.br/

Mazhawu, E. (2016). The effect of shadenetting on '3-29-5' avocado production under subtropical conditions. Master's thesis, University of KwaZulu-Natal, Pietermaritzburg, South Africa.

Mickelbart, M. V., Bender, G. S., Witney, G. W., Adams, C., \& Arpaia, M. L. (2007). Effects of clonal rootstocks on 'Hass' avocado yield components, alternate bearing and nutrition. The Journal of Horticultural Science and Biotechnology, 82(3), 460-466. doi: 10. 1080/14620316.2007.11512259

Organisation for Economic Co-operation and Development (2004). International standardisation: avocados. Recovered from http://www.oecd.org/tad/code/4659 0985.pdf 
Salata, M., \& Sampaio, A. C. (2008). Abacate: aspectos técnicos da produção. São Paulo: Cultura Acadêmica.

Sentelhas, P.C.,Piza, C.T., Jr., Alfonsi, R.R., Kavati, R., \& Soares, N. B. (1995). Zoneamento climático da época de maturação do abacate no Estado de São Paulo. Revista Brasileira de Agrometeorologia, 3, 133140. doi: $10.1590 / 0100-2945-286 / 13$

Stones, W. A., Van-Rooyen, Z., \& Köhne, J. S. (2017). Growing avocados under shade netting. South African Avocado Growers' Association Yearbook, 40, 123-128. Recovered from http://www. avocadosource.com/Journals/SAAGA/ SAAGA_2017/SAAGA_2017_40_PG_ 123.pdf
Van-Rooyen, Z. (2011). New developments in horticultural research at Westfalia, South Africa. Proceedings of the World Avocado Congress, Cairns, Queensland, Austrália, 7.

Whiley, A. W., Wolstenholme, B. N., \& Faber, B. A. (2013). Crop management. In B. Schaffer, B. N. Wolstenholme, \& A. W. Whiley (Eds.), The avocado: botany, production and uses (pp. 342-379). Wallingford: $C A B$ International Press. 